\title{
James P. Stannard, James L. Cook, Lisa A. Fortier: Biologics in orthopaedic surgery
}

\author{
Thieme Verlag, New York, Stuttgart, Delhi, Rio de Janeiro, 2015; \\ Hardcover-130 pp, 21 illustr, €89.99, ISBN: 978-1-62623-200-6
}

Pierre Kehr ${ }^{1}$

Received: 15 March 2016/Accepted: 25 April 2016/Published online: 10 June 2016

(C) Springer-Verlag France 2016

One has found the use of biological products in orthopaedy for about 10 year primarily to support the osseous consolidation.

New products such as the PRP, the stem cells, the serums autologists quickly appeared. New indications were discovered in the chronic diseases, osteoarthritis and in medicine of the sport.

The increasingly broad use of these products requires to know them well and control their instructions, their indications and against indications like their results. The regulation differs from country to country and must be known before the use of these products.
The purpose of this little book is to answer these questions and will interest all the surgeons beginners or who are interested in these new means of treatment.

The various chapters written by American and European authors should make it possible to answer the major part of the questions which a surgeon puts at the present time.

Compliance with ethical standards

Conflict of interest None.

Pierre Kehr

pierre.kehr@gmail.com

1 Strasbourg, France 